\title{
PENGARUH PENAMBAHAN LIMBAH PLASTIK LDPE SEBAGAI BAHAN SUBSTITUSI ASPAL PADA PERKERASAN LENTUR LANDAS PACU
}

\author{
Kristian Wardana Situngkir \\ Jurusan/Program Studi Teknik Sipil, Fakultas Teknik, Universitas Palangka Raya \\ Jln. Hendrik Timang, Kota Palangka Raya, e-mail: kristianwardanasitungki097@gmail.com \\ Salonten \\ Jurusan/Program Studi Teknik Sipil, Fakultas Teknik, Universitas Palangka Raya \\ Jln. Hendrik Timang, Kota Palangka Raya, e-mail: salonten@jts.upr.ac.id \\ Mohamad Amin \\ Jurusan/Program Studi Teknik Sipil, Fakultas Teknik, Universitas Palangka Raya \\ Jln. Hendrik Timang, Kota Palangka Raya,e-mail: burhan_plk17@yahoo.co.id
}

\begin{abstract}
The lot of plastic waste that still cannot be recycled massively, especially plastic type Low Density Polyethylene (LDPE)/plastic bag so researchers want to try using it as an asphalt substitution material in the airport runway mixture concomitant of Tjilik Riwut airport in Palangka Raya City construction increased also. This research tries to analyze the effect of adding LDPE plastic waste as a substitution for asphalt penetration 60/70 on Marshall mix characteristics. The method used in this study uses asphalt institute method. Marshall testing in this study was conducted in 2 stage: first stage to get Optimum Asphalt Content (OAC) and second stage testing the mixture with LDPE plastic substitution of the OAC value obtained from the first stage with a variation of plastic content $4 \%, 8 \%, 12 \%$ and $16 \%$. The results of the first phase of the study were obtained OAC of $6.48 \%$ resulting in stability values of $1531 \mathrm{~kg}$, flow of $3.21 \mathrm{~mm}$, cavities in mix $3.62 \%$, asphalt filled cavities $80.2 \%$, and fill weight of 2,331 grams $/ \mathrm{cm} 3$. The results of evaluating Marshall characteristics from the second stage of $8 \%$ and $12 \%$ plastic content meet all the specified specifications. From the results of tests conducted, the optimum plastic substitution level was obtained at $8.90 \%$, resulting in a stability value of $531 \mathrm{~kg}$, an increase in flow value of 0.6 $\mathrm{mm}$, a cavity in the mixture (VIM) down $0.12 \%$, an asphalt filled cavity (VFB) decreased by $0.6 \%$, and the weight of contents increased by $0.01 \mathrm{gram} / \mathrm{cm}^{3}$.
\end{abstract}

Keywords: substitution of asphalt, runway, LDPE plastic

\begin{abstract}
Abstrak: Banyaknya sampah plastik yang masih belum bisa didaur ulang secara maksimal terutama sampah plastik Low Density Polyethylene (LDPE)/ kresek, sehingga pada penelitian tersebut dicoba dimanfaatkan sebagai bahan substitusi aspal pada campuran landas pacu bandar udara Tjilik Riwut di kota Palangka Raya seiring pembangunannya yang juga semakin meningkat. Penelitian ini menganalisis karakteristik Marshall campuran dengan substitusi aspal penetrasi 60/70 dengan limbah plastik LDPE serta pengaruhnya terhadap campuran. Pengujian dilakukan dengan metode asphalt institute. Pengujian Marshall di dalam penelitian ini dilakukan dengan 2 tahap: tahap ke-1 untuk mendapatkan Kadar Aspal Optimum (KAO) dan tahap ke-2 pengujian campuran dengan substitusi plastik LDPE terhadap nilai KAO yang diperoleh dari tahap ke-1 dengan variasi kadar plastik $4 \%, 8 \%, 12 \%$ dan $16 \%$. Hasil dari penelitian tahap ke-1 diperoleh KAO sebesar 6,48\% menghasilkan nilai stabilitas $1531 \mathrm{~kg}$, flow $3,21 \mathrm{~mm}$, rongga dalam campuran $3,62 \%$, rongga terisi aspal $80,2 \%$, serta berat isi $2,331 \mathrm{gram} / \mathrm{cm}^{3}$. Hasil evaluasi karakteristik Marshall dari tahap ke-2 kadar plastik $8 \%$ dan $12 \%$ memenuhi untuk semua spesifikasi yang ditentukan. Dari hasil pengujian yang dilakukan maka diperoleh kadar substitusi plastik optimum sebesar 8,90\% menghasilkan nilai stabilitas turun sebesar $531 \mathrm{~kg}$, nilai flow naik $0,6 \mathrm{~mm}$, rongga dalam campuran (VIM) turun $0,12 \%$, rongga terisi aspal (VFB) turun $0,6 \%$, dan berat isi naik $0,01 \mathrm{gram} / \mathrm{cm}^{3}$.
\end{abstract}

Kata Kunci: substitusi aspal, landas pacu, plastik LDPE 


\section{PENDAHULUAN}

\section{Latar Belakang}

Menurut data statistik persampahan domestik Indonesia, jenis sampah plastik menduduki peringkat kedua di dunia sebesar 5.4 juta ton per tahun atau 14 persen dari total produksi sampah dunia (Statistik Lingkungan Hidup Indonesia, 2018). Plastik merupakan bahan campuran yang mengandung senyawa polimer, dimana senyawa tersebut baik digunkan sebagai modifer campuran beraspal. Salah satu jenis perkerasan yang sering digunakan di Indonesia untuk perencanaan runway adalah perkerasan lentur sehingga plastik berpotensi untuk dijadikan bahan tambah pada campuran beraspal/ perkerasan lentur.

Aspal modifikasi adalah aspal minyak yang ditambah dengan beberapa aditif, dengan maksud untuk meningkatkan kinerjanya, seperti penambahan polimer, plastik, arang dan lain sebagainya. Untuk menghindari terjadinya alur diberikan penambahan bahan aditif untuk meningkatkan kinerja aspal salah satunya penambahan plastik jenis Low Density Polyethylene (LDPE) atau lebih dikenal dengan Plastik Kresek.

\section{Rumusan Masalah}

1. Berapa nilai karaktersistik Marshall yang dihasilkan menggunakan limbah plastik Low Density Polyethylene (LDPE) sebagai bahan substitusi aspal penetrasi 60/70 dengan variasi kadar plastik $4 \%, 8 \%, 12 \%$, dan $16 \%$ terhadap $\mathrm{KAO}$ ?

2. Bagaimana pengaruh substitusi aspal menggunakan limbah plastik LDPE pada campuran Asphalt Concrete landas pacu?

\section{Batasan Masalah}

Batasan-batasan dalam penelitian ini, yaitu:

1. Aspal yang digunakan adalah aspal dengan penetrasi 60/70.

2. Bahan yang digunakan sebagai bahan substitusi aspal adalah plastik kresek bekas yang termasuk jenis plastik Low Density Polyethylene (LDPE), dipotong dengan ukuran panjang dan lebar \pm 1 $\mathrm{cm}$, kemudian dicampurkan bersamaan dengan campuran aspal yang dipanaskan.

3. Perubahan kimia yang terjadi dalam campuran aspal dengan bahan aditif plastik tidak ditinjau beserta besarnya pengaruhnya dari segi ekonomi.

\section{Tujuan dan Manfaat}

Tujuan yang diharapkan dari penelitian ini adalah mengetahui sejauh mana pengaruh penggunaan limbah plastik LDPE sebagai bahan substitusi aspal pada campuran untuk landas pacu pesawat dilihat dari nilai parameter Marshallnya. Penggunan limbah plastik LDPE sebagai bahan pengganti aspal dapat menjadi salah satu alternatif pengurangan limbah plastik Low Density Polyethylene (LDPE) sehingga meningkatkan nilai ekonomis dan fungsinya.

\section{TINJAUAN PUSTAKA}

\section{Bandar Udara}

Bandar udara adalah lapangan terbang yang dipergunakan untuk mendarat dan lepas landas pesawat udara, naik turun penumpang, dan/atau bongkar muat kargo dan/atau pos, serta dilengkapi dengan fasilitas keselamatan penerbangan juga sebagai tempat perpindahan antar moda (Peraturan Jenderal Perhubungan, 2005).

Fungsi Bandar Udara yaitu untuk menunjang kelancaran, keamanan dan ketertiban arus lalu lintas pesawat udara, kargo dan/atau pos, keselamatan penerbangan, tempat perpindahan intra dan/atau moda serta mendorong perekonomian baik daerah maupun secara nasional. Tatanan Kebandarudaraan nasional yang mengatur penyelenggaraan Bandar Udara sesuai dengan fungsi, penggunaan, klasifikasi, status, penyelenggaraan dan kegiatan Bandar Udara.

\section{Konfigurasi Bandar Udara}

Konfigurasi bandar udara adalah jumlah dan arah orientasi dari landasan serta penempatan bangunan terminal termasuk lapangan parkirnya yang relatif terhadap landasan pacu.

Penempatan landasan hubung (Taxiway) pun harus benar-benar tepat sehingga lokasinya memberi kemudahan dalam melayani penupang. Orientasi yang paling penting dalam perencanaan bandar udara adalah: Landasan pacu (Runway, landasan hubung (Taxiway) dan tempat parkir (Apron) (Ravandy, 2019).

\section{Landas Pacu}

Landas Pacu adalah suatu daerah persegi panjang yang ditentukan pada bandar udara di kawasan daratan dan/atau perairan yang dipergunakan untuk pendaratan dan lepas landas pesawat udara. Sistem runway terdiri dari perkerasan struktur, bahu landasan (shoulder), bantal hembusan (blast pad), dan daerah aman runway (runway end safety area) (Horonjeff, 1993). 


\section{Struktur Perkerasan Landasan Pacu}

Perkerasan adalah struktur yang terdiri dari beberapa lapisan dengan kekerasan dan daya dukung yang berlainan. Perkerasan yang dibuat dari campuran aspal dengan agregat digelar di atas suatu permukaan material granular mutu tinggi disebut perkerasan lentur.

Perkerasan dibuat dengan tujuan untuk memberikan permukaan yang halus dan aman pada segala kondisi cuaca, serta ketebalan dari setiap lapisan harus cukup aman untuk menjamin bahwa beban pesawat yang bekerja tidak merusak perkerasan lapisan di bawahnya (Basuki, 1986). Perkerasan lentur terdiri dari satu lapisan bahan atau lebih yang digolongkan sebagai lapisan permukaan (surface course), lapisan pondasi atas (base course), dan lapisan pondasi bawah (subbase course) yang terletak di atas lapisan tanah dasar (subgrade) yang telah dipersiapkan.

\section{Perencanaan Perkerasan Runway dan Taxiway}

Dalam merencanakan perkerasan suatu landasan pacu, terdapat berbagai metode-metode yang digunakan untuk mendesain perkerasannya. Pola penyelesainnya pun berbeda-beda, namun semuanya bertujuan untuk menghasilkan desain perkerasan yang aman dan terjamin. Menurut Basuki (1986), yaitu:

1. Metode US Corporation Of Engineers lebih dikenal dengan metode CBR.

2. Metode FAA.

3. Metode LCN dari Inggris.

4. Metode Asphalt Institute.

5. Metode Canadian Departement of Transportation

\section{Aspal Beton (Asphalt Concrete)}

Asphalt Concrete merupakan aspal panas (hotmix) yang digunakan sebagai lapis permukaan. Secara umum komposisi campuan asphalt concrete terdiri dari agregat kasar (course aggregate), agregat sedang (medium aggregate), agregat halus (fine aggregate) yang berupa abu batu serta aspal (Ravandy, 2019). Bahan penyusun campuran Asphalt Concrete untuk bandar udara telah di tetapkan oleh Direktorat Jenderal Perhubungan Udara pada Pedoman Penyusunan Rencana Kerja dan Syarat-syarat (RKS) dan Spesifikasi Teknis Pekerjaan Fasilitas Sisi Udara Bandar Udara Tahun 2014, yaitu aspal, agregat, dan filler.

Dalam desain sebuah campuran bitumen/aspal hal yang perlu diperhatikan adalah memilih tipe agregat, mutu agregat, mutu aspal, modifer aspal (jika diperlukan), dan untuk menentukan kadar aspal yang dapat berkerja paling optimum selama kurun waktu umur perkerasan tersebut. Komposisi bahan dalam campuran beraspal panas terlebih dahulu harus direncanakan sehingga setelah terpasang diperoleh perkerasan aspal yang memenuhi kriteria (Sukirman, 2003).

\section{Aspal}

Aspal didefinisikan sebagai suatu cairan yang lekat atau berbentuk padat, yang terdiri dari hydrocarbons atau turunannya, terlarut dalam trichloro-ethylene dan bersifat tidak mudah menguap serta lunak secara bertahap jika dipanaskan. Aspal berwarna hitam atau kecokelatan, memiliki sifat kedap air dan adhesive (British Standart, 1989 ).

Terdapat bermacam-macam tingkat penetrasi aspal yang dapat digunakan dalam campuran agregat aspal, antara lain penetrasi 40/50, 60/70, 80/100.

\section{Agregat}

Menurut Sukirman (1999) mendefinisikan Agregat/batuan sebagai formasi kulit bumi yang keras atau penyal (solid) yang merupakan komponen utama dari lapisan perkerasan jalan yaitu mengandung $90-95 \%$ agregat berdasarkan persentase berat atau $75-85 \%$ agregat berdasarkan persentase volume. Dengan demikian daya dukung, keawetan dan mutu perkerasan jalan ditentukan juga dari sifat agregat dan hasil campuran agregat dengan material lain.

Agregat dapat diperoleh secara alami atau buatan. Agregat yang terjadi secara alami adalah pasir, kerikil dan batu. Kebanyakan agregat memerlukan beberapa proses seperti dipecah, dicuci sebelum agregat tersebut digunakan. Klasifikasi agregat dapat dilakukan melalui beberapa cara, yaitu klasifikasi berdasarkan sumber bahan (resource) dan dimensi butiran.

\section{Plastik Low Density Polyethylene (LDPE)}

Plastik jenis Polytehylene (PE) dapat dibagi menurut massa jenisnya menjadi dua jenis, yaitu: Low Density Polyethylene (LDPE) dan High Density Polyethylene (HDPE). LDPE mempunyai massa jenis antara $0,91-0,94 \mathrm{~g} / \mathrm{mL}$, separuhnya berupa kristalin (50-60\%) dan memiliki titik leleh $115^{\circ} \mathrm{C}$.

\section{Penelitian Terdahulu}

1. Fitri, S., Saleh, S. M., \& Isya, M. (2018), dalam Jurnal yang berjudul "Pengaruh Penambahan Limbah Plastik Kresek sebagai Substitusi Aspal Pen 60/70 terhadap Karakteristik Campuran 
Laston AC-BC" disimpulkan nilai stabilitas campuran dengan aditif meningkat.

2. Yahya (2018), dalam tugas akhir yang berjudul "Analisis Karakteristik Marshall Campuran Hot Rolled Sheet Wearing Course (HRS-WC) menggunakan Bahan Tambah Plastik Bekas Jenis Polyethylene Terephathalate (PET)". Kesimpulan dari hasil penelitian ini untuk nilai karakteristik Marshallnya meningkat untuk Stabilitas naik sebesar $78 \mathrm{~kg}$, Flow bertambah $0,25 \mathrm{~mm}$, VFB bertambah $4,30 \%$.

\section{METODE PENELITIAN}

\section{Umum}

Penelitian ini menggunakan metode uji laboratorium, yaitu untuk mengetahui manfaat dari limbah plastik Low Density Polyethylene (LDPE) atau plastik kresek sebagai bahan substitusi sebagian pada aspal penetrasi 60/70 pada perkerasan lentur landas pacu Bandar Udara. Dalam penelitian di laboratorium diadakan pengamatan dan pemeriksaan terhadap proporsi campuran yang memenuhi spesifikasi. Data yang dihasilkan digunakan untuk perancangan campuran, selanjutnya dibuat benda uji (briket) untuk dilakukan uji Marshall sehingga diketahui karakteristik campuran tersebut.

\section{Pengambilan Material}

Pengambilan material berupa agregat batu pecah yang diambil dari Kecamatan Kurun Kabupaten Gunung Mas selanjutnya akan dilakukan pemeriksaan sifat-sifat fisik agregat.

\section{Pengambilan Data Sampel}

Pengambilan data dilakukan dengan membuat briket/benda uji sebanyak 27 buah. Benda uji tersebut dibagi dalam 3 kali percobaan, yaitu:

a. Percobaan pertama dibuat 15 briket/benda uji yang terdiri dari 1 macam komposisi terbaik yang mendekati spesifikasi dengan 5 variasi kadar aspal. Tiap variasi kadar aspal dibuat 3 buah briket/benda uji yang kemudian hasilnya dirataratakan untuk kemudian didapatkan nilai Kadar Aspal Optimum (KAO).

b. Percobaan kedua, dalam percobaan ini Kadar Aspal Optimum (KAO) yang didapat pada percobaan pertama selanjutnya dipergunakan sebagai kadar aspal untuk memuat 12 buah briket/benda uji, yang terdiri dari 4 variasi persentase substitusi plastik Low Density Polyethylene (LDPE) terhadap berat Kadar Aspal Optimum (KAO), sebesar 4\%, 8\%, 12\%, dan $16 \%$. Tiap variasi persentase berat plastik
Polyethylene (LDPE) dibuat 3 buah briket/benda uji.

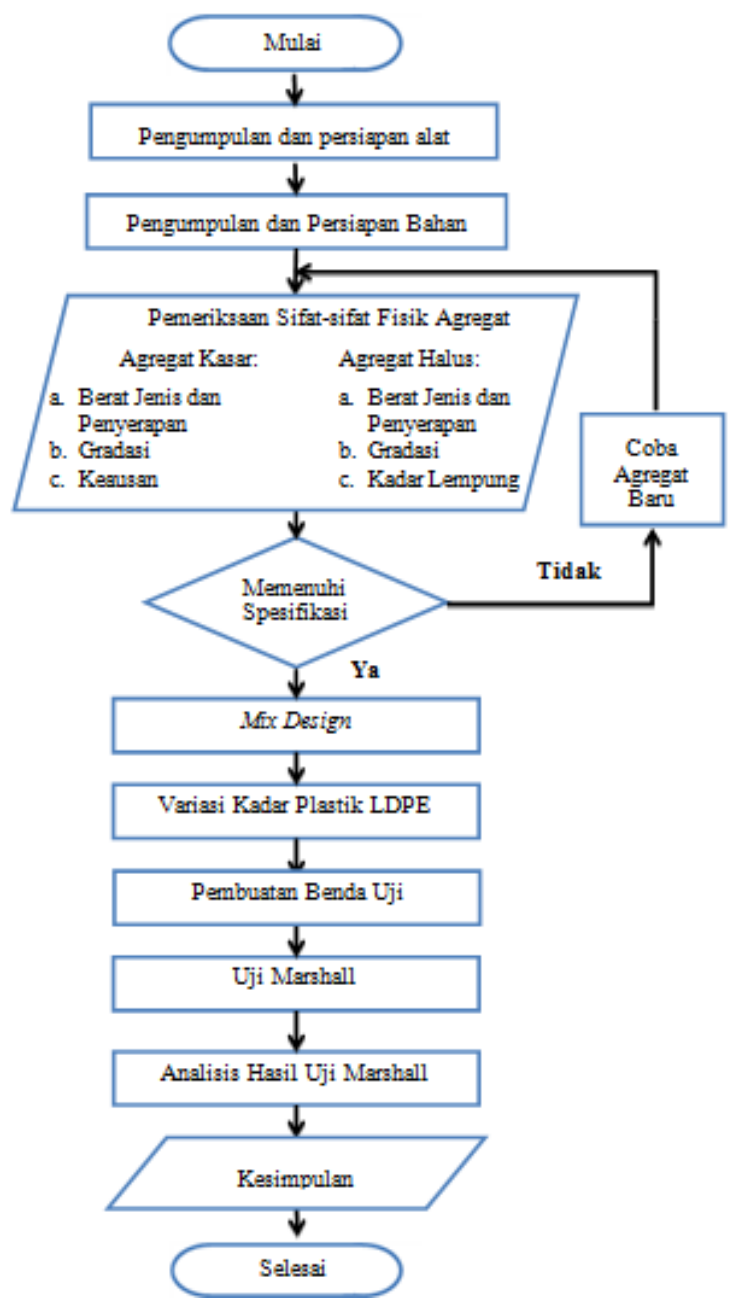

Gambar 1. Bagan alir

\section{ANALISIS DAN PEMBAHASAN}

\section{Pengujian Marshall}

Pembuatan briket atau benda uji. Pembuatan benda uji mengikuti prosedur pada SNI 06-24891991. Sifat karakteristik Marshall terhadap kadar aspal seperti berikut pada Gambar 2.

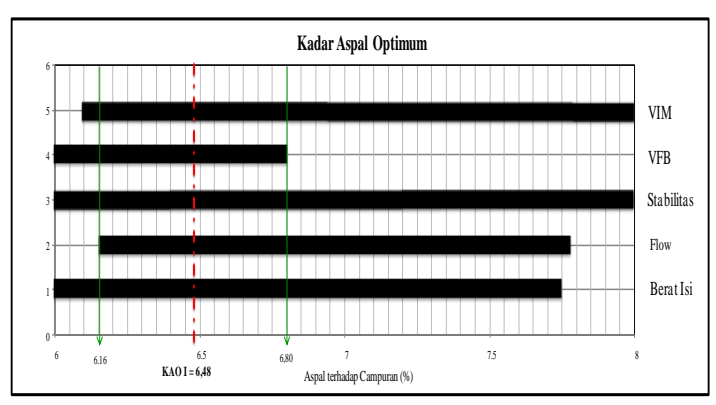

Gambar 2. Grafik hubungan nilai parameter Marshall terhadap Kadar Aspal Optimum (KAO) 
Hasil evaluasi sifat fisik menunjukkan bahwa pada rentang kadar aspal $6,16 \%$ hingga $6,80 \%$ campuran memenuhi semua persyaratan yang ditentukkan. Berdasarkan rentang tersebut diambil nilai tengah rentang yaitu $6,48 \%$ sebagai KAO untuk Komposisi I. Dari hasil pengujian maka didapat hasil evaluasi sifat marshall Komposisi I pada KAO $6,48 \%$ sebesar 83,148 gram.

Tabel 1. Nilai parameter karakteristik marshall pada kadar aspal optimum

\begin{tabular}{ccccc}
\hline No. & $\begin{array}{c}\text { Sifat } \\
\text { Marshall }\end{array}$ & Nilai & Persyaratan & Satuan \\
\hline 1 & Stabilitas & 1531 & $\geq 998,8$ & $\mathrm{Kg}$ \\
2 & Flow & 3,21 & $4-\mathrm{Feb}$ & $\mathrm{mm}$ \\
3 & VIM & 3,62 & $4-\mathrm{Mar}$ & $\%$ \\
4 & VFB & 80,2 & $76-82$ & $\%$ \\
5 & Berat Isi & 2,331 & $\geq 2,303$ & $\mathrm{gr} / \mathrm{cm}^{3}$ \\
\hline
\end{tabular}

Dari tabel diatas bahwa diperoleh nilai parameter marshall dari KAO Komposisi I memiliki Stabilitas sebesar $1531,00 \mathrm{~kg}$, flow sebesar 3,21 mm, VIM sebesar 3,26\%, VFB sebesar 80,20\% dan berat isi sebesar 2,331 $\mathrm{gram} / \mathrm{cm}^{3}$.

Hasil pengujian parameter karakteristik Marshall Komposisi II pada campuran dengan variasi persentase limbah plastik Low Density Polyrthylene (LDPE) sebagai bahan substitusi terhadap KAO dapat dilihat pada Tabel 2 berikut.

Tabel 2. Nilai parameter karakteristik marshall dengan plastik LDPE sebagai bahan subsitusi aspal

\begin{tabular}{|c|c|c|c|c|c|}
\hline \multirow{3}{*}{$\begin{array}{c}\text { Kadar } \\
\text { Plastik } \\
\text { LDPE } \\
\text { terhadap } \\
\text { Berat Aspal } \\
\quad(\%)\end{array}$} & \multicolumn{5}{|c|}{ Parameter Karakteristik Marshall } \\
\hline & Stabilitas & Flow & VIM & VFB & Berat Isi \\
\hline & $(\mathrm{kg})$ & $(\mathrm{mm})$ & $(\%)$ & $(\%)$ & $(\mathrm{gr} / \mathrm{cm} 3)$ \\
\hline 0 & 1531 & 3,21 & 3,62 & 80,2 & 2,331 \\
\hline 4 & 1083,489 & 3,72 & 3,274 & 82,141 & 2,342 \\
\hline 8 & 1038,793 & 3,69 & 3,346 & 81,488 & 2,342 \\
\hline 12 & 1093,44 & 3,86 & 3,993 & 78,877 & 2,329 \\
\hline 16 & 1321,399 & 3,98 & 4,294 & 76,748 & 2,325 \\
\hline Spek. & $>998,8$ & $3-4$ & $3-4$ & $76-82$ & $>2,303$ \\
\hline
\end{tabular}

Hasil dari pengujian Marshall pada Komposisi II menunjukkan bahwa pada kadar Plastik 4\% dan $16 \%$ tidak memenuhi spesifikasi, pada kadar plastik $4 \%$ (VFB lebih dari 82\%) dan 16\% (VIM lebih dari $4 \%$ ). Sedangkan substitusi Plastik LDPE sebesar $8 \%$ dan $12 \%$ memenuhi Spesifikasi. Nilai parameter 60 marshall dengan kadar plastik $4 \%$ dan $8 \%$ berturutturut adalah : Stabilitas 1038,798:1093,440 (kg); Flow 3,69 : 3,86 (mm); VIM 3,346: 3,993 (\%); VFB 81,48: $\quad 78,877(\%)$; Berat isi 2,342: 2,329342 $\left(\mathrm{gr} / \mathrm{cm}^{3}\right)$.

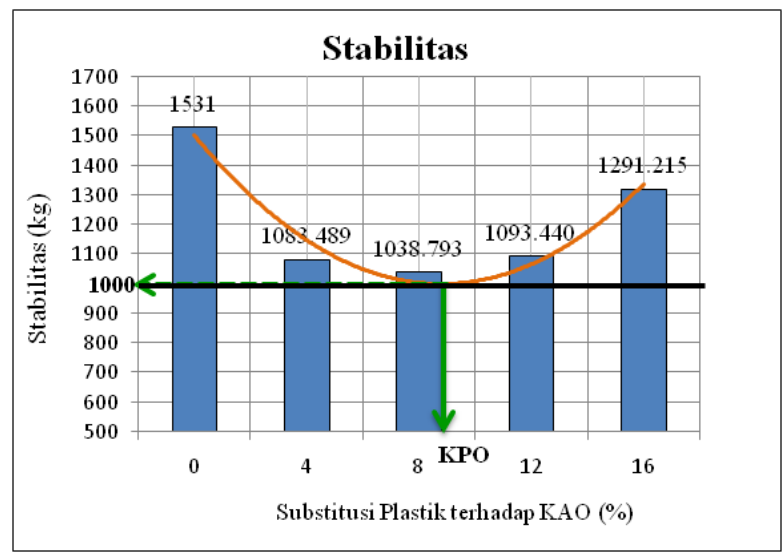

Gambar 3. Grafik hasil hubungan stabilitas terhadap variasi kadar plastik LDPE sebagai bahan substitusi aspal

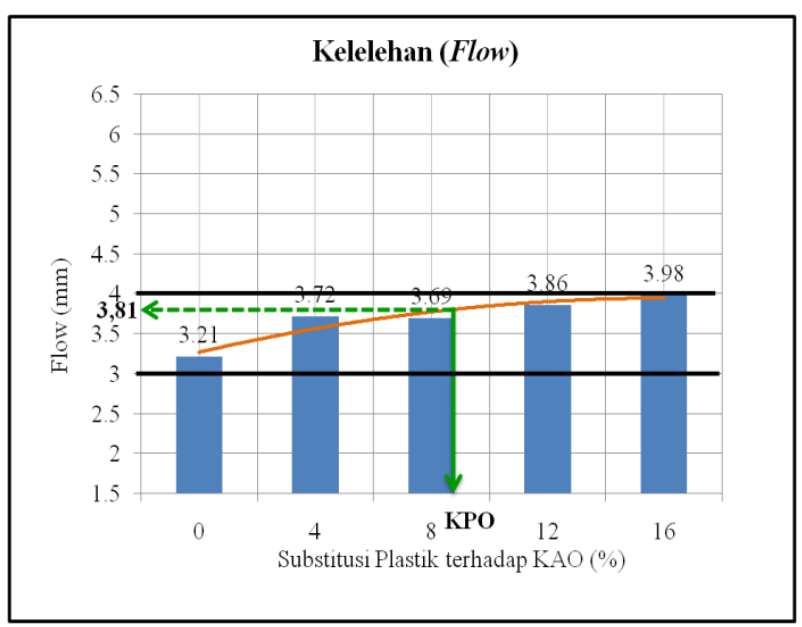

Gambar 4. Grafik hasil hubungan kelelehan (flow) terhadap variasi kadar plastik LDPE sebagai bahan substitusi aspal

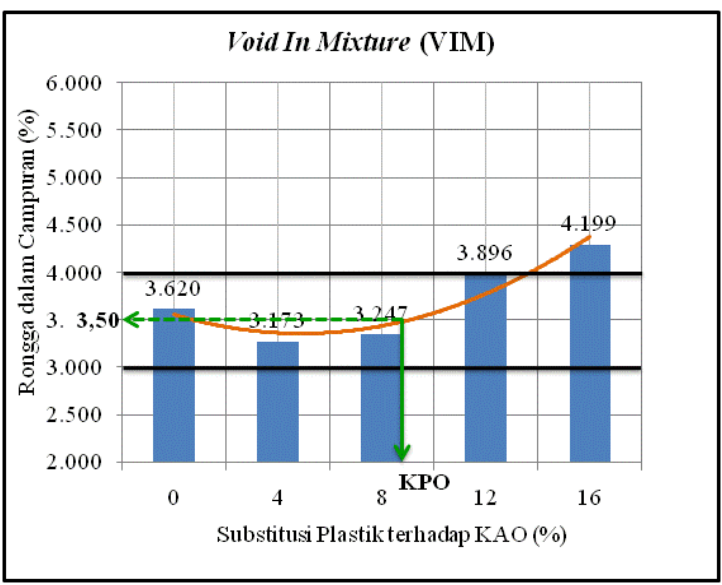

Gambar 5. Grafik hasil hubungan VIM terhadap variasi kadar plastik LDPE sebagai bahan substitusi aspal 


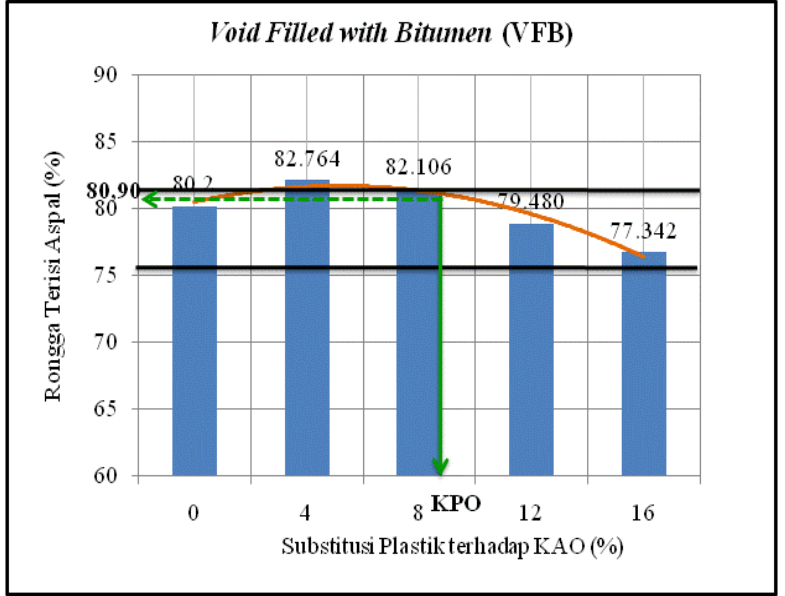

Gambar 6. grafik hasil hubungan VFB terhadap variasi kadar plastik LDPE sebagai bahan substitusi aspal

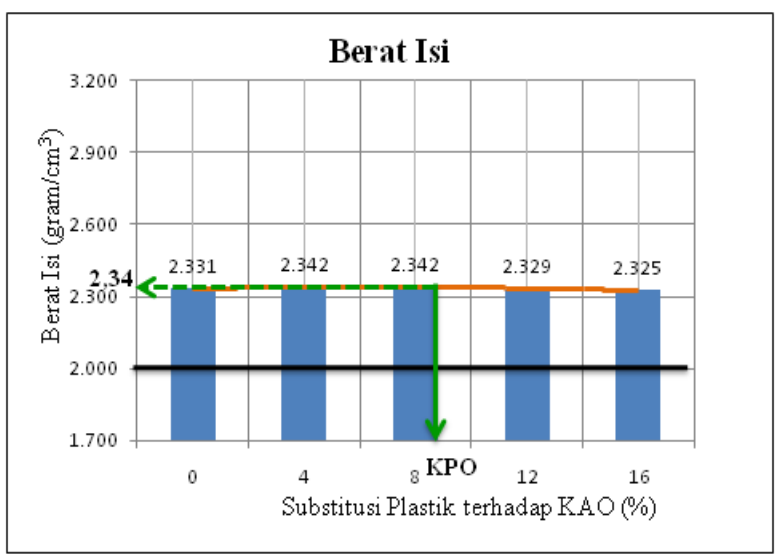

Gambar 7. Grafik hasil hubungan berat isi terhadap variasi kadar plastik LDPE sebagai bahan substitusi aspal

Dari hasil pengujian Marshall campuran dengan substitusi plastik LDPE terhadap kadar aspal pada campuran, maka didapat hasil perbandingan nilai parameter Marshall dapat dilihat pada Tabel 3.

Tabel 3. Nilai karakteristik marshall campuran dengan substitusi plastik LDPE optimum

\begin{tabular}{ccccccc}
\multicolumn{8}{c}{ Substitusi plastik LDPE optimum } \\
Komp. & KPO & $\begin{array}{c}\text { Stabilta } \\
\text { s (kg) }\end{array}$ & $\begin{array}{c}\text { Flow } \\
(\mathrm{mm})\end{array}$ & $\begin{array}{c}\text { VIM } \\
(\%)\end{array}$ & $\begin{array}{c}\text { VFB } \\
(\%)\end{array}$ & $\begin{array}{c}\text { Berat Isi } \\
\left(\mathrm{kg} / \mathrm{cm}^{3}\right)\end{array}$ \\
\hline I & $0 \%$ & 1531 & 3,21 & 3,62 & 80,2 & 2,331 \\
II & $8,90 \%$ & 1000 & 3,81 & 3,5 & 80,9 & 2,34 \\
Spesifikasi & $\geq 998,8$ & $3-4$ & $3-4$ & $76-82$ & $\geq 2,303$ \\
\hline
\end{tabular}

Tabel diatas menunjukkan bahwa kadar substitusi plastik LDPE terhadap KAO I paling Optimum pada $8,90 \%$. Pemanfaatan limbah plastik LDPE sebagai bahan substitusi terhadap aspal pada campuran sebesar $8,90 \%$ dapat mengurangi penggunaan kadar aspal terhadap campuran sebesar $0,577 \%$, dari nilai stabilitas campuran tanpa menggunakan plastik LPDE sebagai bahan substitusi aspal dengan menggunkan plastik LDPE sebagai bahan substitusi aspal mengalami penurunan sebesar $531 \mathrm{~kg}$, nilai flow naik sebesar $0,6 \mathrm{~mm}$, rongga udara dalam campuran turun sebesar $0,12 \%$, rongga terisi aspal $0,6 \%$, dan berarti isi naik $0,01 \mathrm{gram} / \mathrm{cm}^{3}$.

\section{PENUTUP}

\section{Kesimpulan}

1. Hasil penelitian terhadap parameter karaktersitik Marshall yang dihasilkan menggunakan komposisi agregat sama dengan komposisi I dan plastik jenis Low Density Polyethylene (LDPE) sebagai bahan substitusi aspal penetrasi 60/70 dengan variasi kadar plastik 4\%, 8\%, 12\%, dan 16\% terhadap Kadar Aspal Optimum (KAO I), dihasilkan karakteristik parameter Marshall sebagai berikut:

a. Nilai stabilitas untuk semua kadar plastik telah memenuhi spesifikasi. Nilai stabilitas tertinggi pada kadar Plastik LDPE $16 \%$ yaitu $1321,399 \mathrm{~kg}$ dan nilai stabilitas terendah pada kadar substitusi Plastik LDPE $8 \%$ yaitu $1038,793 \mathrm{~kg}$.

b. Nilai kelelehan (Flow) pada campuran untuk semua kadar substitusi limbah plastik LDPE telah memenuhi spesifikasi. Nilai Flow pada kadar Plastik LDPE 8\% hingga 16\% cenderung meningkat. Nilai Flow tertinggi pada kadar plastik $16 \%$ sebesar 3,98 mm dan terendah pada kadar $8 \%$ sebesar 3,69 mm.

c. Nilai rongga udara dalam campuran (VIM) pada kadar plastik rentang $4 \%$ hingga $12 \%$ memenuhi spesifikasi, tetapi pada kadar $16 \%$ (VIM 4,294\%) tidak memenuhi spesifikasi. Dapat disimpulkan bahwa semakin besar kadar substitusi plastik LDPE pada campuran, maka nilai VIM nya juga akan meningkat.

d. Nilai rongga terisi aspal (VFB) pada kadar plastik $8 \%$ hingga $16 \%$ sudah memenuhi spesifikasi, sedangkan untuk kadar substusi plastik 4\% (VFB 82,141\%) tidak memenuhi spesfikasi karena lebih dari $82 \%$. Sehingga dapat disimpulkan bahwa semakin besar substitusi plastik LDPE pada campuran, maka nilai VFB akan cenderung menurun dikarenakan semakin bertambahnya substitusi plastik terhadap kadar aspal.

e. Nilai berat jenis pada campuran dengan substitusi plastik LDPE terhadap kadar aspal untuk semua presentasenya memenuhi spesifikasi. Nilai Berat Jenis campuran 
semakin rendah seiring semakin besar kadar substitusi plastik LDPE.

2. Pengaruh substitusi plastik LDPE terhadap aspal pada campuran, yaitu kadar substitusi limbah plastik LDPE optimum terhadap aspal sebesar $8,90 \%$, sehingga penggunaan kadar aspal pada campuran dari $6,48 \%$ menjadi $5,90 \%$. Nilai stabilitas pada campuran mengalami penurunan $531 \mathrm{~kg}$, nilai flow naik sebesar $0,6 \mathrm{~mm}$, rongga udara dalam campuran turun sebesar $0,12 \%$, rongga terisi aspal $0,6 \%$, dan berati isi naik 0,01 $\mathrm{gram} / \mathrm{cm}^{3}$.

\section{SARAN}

Setelah melakukan penelitian ini, dapat disampaikan beberapa saran sebagai berikut:

1. Diharapkan untuk penelitian berikutnya dapat memanfaatkan limbah plastik dengan jenis yang berbeda dengan plastik LDPE (plastik kresek).

2. Pada penelitian berikut bisa digunakan jenis campuran yang berbeda.

3. Diharapkan pada penelitian lebih lanjut dapat ditinjau pengaruh pemanfaatan limbah plastik sebagai bahan substitusi aspal dari segi ekonominya.

4. Diharapkan penelitian tersebut dapat diaplikasikan dilapangan, sehingga pengaruh plastik yang digunakan sebagai substitusi aspal tersebut dapat dilihat secara nyata misalnya retakan yang terjadi pada landas pacu, lendutan akibat beban pada perkerasan dan lain sebagainya.

\section{DAFTAR PUSTAKA}

Anonim. 2014. Pedoman Penyusun Rencana Kerja dan Syarat-syarat (RKS) dan Spesifikasi Teknis Pekerjaan Fasilitas Sisi Udara Bandar Udara. Direktorat Jenderal Perhubungan Udara.

Anonim, 2018. Statistik Lingkungan Hidup Indonesia Pengelolaan Sampah Indonesia. Jakarta. Badan Pusat Statistik Indonesia

Basuki, H. (1986). Merancang dan Merencanakan Lapangan Terbang. Bandung : Alumni.

Fitri, S., Saleh, S. M., \& Isya, M. (2018). "Pengaruh Penambahan Limbah Plastik Kresek sebagai Substitusi Aspal Pen 60/70 terhadap Karakteristik Campuran Laston AC-BC”. Jurnal Teknik Sipil Universitas Syiah Kuala, 1(3), pp. 737-748.
Horonjeff. (1993). "Perencanaan Dan Perancangan Bandar Udara”. Erlangga, Jakarta 10430.

Ravandy, V. (2019). Analisis Penggunaan Batu Pecah Kecamatan Kurun Kabupaten Gunung Mas sebagai Material Campuran Asphalt Concrete (AC) untuk Landas Pacu Bandar Udara Tjilik Riwut. Tugas Akhir Jurusan/Program Studi Teknik Sipil Universitas Palangka Raya. Palangka Raya.

Sukirman, Silvia. (1999). Dasar-dasar Perencanaan Geometrik Jalan. Bandung : Nova

Sukirman, Silvia (2003) Beton Aspal Campuran Panas. Grafika Yuana Marga: Bandung

SNI 06-2489-1991. (1991). Metode Pengujian Campuran Aspal dengan Alat Marshall. Bandung

Yahya, Y. (2018). Analisis Karakteristik Marshall Campuran Hot Rolled Sheet Wearing-Course (HRS-WC) menggunakan Bahan Tambah Plastik Bekas Jenis Polyethylene Terephthalate (PET). Tugas Akhir Jurusan/Program Studi Teknik Sipil Universitas Palangka Raya. Palangka Raya. 